(2) Open Access Full Text Article

REVIEW

\title{
Improving Adherence to Wearing Compression Stockings for Chronic Venous Insufficiency and Venous Leg Ulcers: A Scoping Review
}

\author{
Laila Bar (D)' \\ Susan Brandis (iD) \\ Darryn Marks iD ${ }^{2}$ \\ 'Department of Occupational Therapy, \\ Bond University, Faculty of Health \\ Science and Medicine, Queensland, \\ Australia; ${ }^{2}$ Department of Physiotherapy, \\ Bond University, Faculty of Health \\ Science and Medicine, Queensland, \\ Australia
}

Purpose: Patient adherence to wearing compression stockings in the management of chronic venous insufficiency (CVI) and venous leg ulcers (VLUs) is low. Poor adherence with compression stockings contributes to recurrence and impaired healing of VLUs. As such, the purpose of this review was to report on the scientific evidence related to adherence and explore modifiable factors which impact adherence with compression stockings.

Methods: A systematic search was conducted from inception to 31 October 2019. Following the PRISMA-ScR Checklist, PubMed, Medline, CINAHL, Cochrane, Embase, OT Seeker and Web of Science were explored using search terms: compression/compression stocking/compression garment/compression sock/stockings/garments and adherence/compliance/concordance.

Results: We identified 2613 papers of which 125 full text papers were assessed for eligibility and 69 met inclusion criteria. Papers were grouped and charted by concepts relevant to the research questions and narratively synthesized. Several dominant themes emerged, and a conceptual framework was developed incorporating modifiable variables, adherence itself, and outcomes related to adherence. Specifically considering interventions to improve adherence, only five of 14 randomized controlled trials were able to demonstrate improvements in adherence through unidimensional approaches. All nine of the case studies/ series demonstrated a positive impact on adherence, eight of which described a personalized multidimensional approach. A lack of consensus around defining, measuring, and quantifying adherence with compression stockings was identified, resulting in wide variation in reported adherence rates.

Conclusion: Inconsistency in the definition and measurement of adherence limits meaningful interpretation of the literature. No individual intervention has consistently demonstrated improved adherence. Multidimensional interventions show promise but require further investigation with high-quality trials. Improving adherence appears to improve health outcomes in VLU /CVI populations but there is a lack of information directly linking improved adherence with cost outcomes.

Trial Registration: Open Science Framework: ACTRN12620000544976p.

Keywords: scoping review, compression stockings, adherence, leg ulcers, chronic venous insufficiency

\section{Plain Language Summary}

Venous leg ulcers are open sores in the skin of the lower legs which are typically painful, heal slowly and expensive to treat. Wearing compression stockings is the best treatment to heal and prevent ulcers, but some patients do not wear their stockings as much as they 
should. That is, adherence to the recommended treatment is low. A review of the literature was conducted to find out what is known about this topic and what information is missing. We discovered that researchers have attempted to improve adherence with wearing compression stockings but are still exploring ways to improve adherence where each person has different reasons (barriers) for not wearing them. Higher adherence rates have been found where authors have identified individual barriers and then developed personalized and multidimensional interventions. However, this can be difficult when dealing with large numbers of people. Interventions that can be used on a large population that firstly identifies patients' barriers before developing personalized treatment plans are required. There is little consistency in the way adherence is scored or measured and to enable future researchers to compare studies, it would be beneficial to have a consistent way to score and measure adherence.

\section{Background}

Venous leg ulcers (VLUs) are open wounds in the skin that occur due to high blood pressure inside the leg. ${ }^{1-3}$ Most often seen in older adults who have chronic venous insufficiency (CVI), they follow a natural cycle of prolonged healing and recurrence ${ }^{2-4}$ and may become chronic, persisting for many years. ${ }^{4}$ VLUs can lead to distress, loss of function and pain. ${ }^{4-6}$ International prevalence studies estimate that between 1.5 and 3.0 per 1000 people have active leg ulcers. ${ }^{4}$ Medically prescribed compression stockings are the gold standard in the long-term management of CVI, to heal and prevent VLUs. ${ }^{1,7-9}$ Compression reduces vein distension, assists calf musculature to pump blood against gravity and lessens oedema. ${ }^{10}$ VLUs are more likely to recur when patients do not comply with compression treatment. ${ }^{11}$ Adherence rates of $12 \%$ to $52 \%{ }^{12}$ indicate many patients do not reap the health benefits of compression therapy. Poor adherence also has large financial implications. ${ }^{13}$ In Australia it is estimated that the cost of healing a VLU could be reduced from AUS\$10743 to $\$ 3883$ per patient if compression stockings were used as prescribed. ${ }^{14}$ Further, if compression stockings were provided to all affected individuals nationally it would cost an additional AUS\$270 million but save AUS\$1.4 billion over five years. $^{15}$

Extensively documented in the literature, multiple nonmodifiable barriers exist to the wearing of compression stockings, including person-related factors, such as age, educational background, and cognition as well as environmental factors like climate, and income. ${ }^{4,16}$ Acknowledging that while there is potential for these to change, for example relocating to a cooler climate, these variables are largely fixed at the time of any patient intervention. On the other hand, other variables are more easily modifiable at the time of intervention and can be addressed by clinicians and researchers, such as stocking type, stocking education and use of assistive devices. Many variables have been described but to date, broad synthesis of the literature pertaining to these factors has not been undertaken.

Improving adherence with compression therapy, presents an opportunity to reduce the personal health burden imposed by VLUs upon patients and benefit wider society economically however, it remains unclear how to do this. A 2016 Cochrane review of interventions to improve adherence to compression therapy in patients with VLUs $^{1}$ yielded only three randomized controlled trials (RCTs). They concluded that there was a lack of highquality trials and uncertainty whether any interventions help. Other reviews on the topic provide some potential insights, despite their inclusion of broader patient groups than VLUs and/or broader adherence domains other than compression therapy. One review ${ }^{17}$ was focused on the impact of compression class in post-thrombotic and VLU populations and found that lower compression classes showed higher adherence. Another ${ }^{18}$ took a more multidimensional perspective by investigating patient reasons for nonadherence to compression therapy, lifestyle advice and exercises. They concluded that patient-perceived pain, and professional advice both influenced adherence and suggested a multidimensional approach is needed. These authors ${ }^{11,18}$ did not synthesize data pertaining to the efficacy of interventions targeting adherence. One older literature review of studies up to 2005, synthesized a variety of study designs of interventions for adherence and revealed some support for a multidimensional approach to improving adherence, but again included the broader adherence criteria of compression, leg exercises and elevation. ${ }^{11}$ Consequently, to ensure clinical practice is up to date and research gaps are targeted, a broad and current literature synthesis, specifically regarding adherence to compression therapy in VLUs, is needed.

There is also ambiguity surrounding the definition and measurement of adherence. ${ }^{11}$ The literature varyingly names adherence as "compliance" or "concordance". In a medical context, these terms indicate the extent to which patients follow the instructions they are given for treatment. ${ }^{19}$ In the context of compression wear, the term 
"adherence" is preferred, as it implies non-judgement; "a statement of fact rather than of blame attributable to the patient, prescriber or compression treatment". ${ }^{17}$ It has been recommended that adherence should be "defined specifically for the situation, with parameters of acceptable adherence carefully delineated" 20 but the literature has suggested a lack of standardization across health behaviors. $^{20}$

Stocking adherence can exist as a bivariate measure, that is the number of days per week as well as the number of hours per day that compression stockings are worn, yet a lack of consistency exists around the way researchers measure it. ${ }^{21}$ The lack of clarity in agreed-upon definitions and scoring methods may confound the interpretation and generalizability of clinical research results. ${ }^{22}$ This highlights the need to look broadly across the adherence literature in the VLU and CVI patient group to describe and synthesize adherence definitions and its measurement, to inform the methodological quality of future research.

Therefore, the aim of this scoping review is to report on the scope and breadth of literature relating specifically to VLU and CVI on adherence with compression stockings particularly in relation to interventions, and how the phenomenon is measured and defined. This will be the first scoping review to look specifically at improving adherence to compression therapy in the VLU and CVI population.

\section{Research Questions}

1. What factors and interventions have been reported in the literature to attempt to improve compression stocking adherence?

2. How has adherence been defined in the literature and how have adherence rates been reported and measured in the population of VLU and CVI?

3. What is the impact of adherence on patient outcomes?

4. What knowledge gaps currently exist?

\section{Methods}

To bring cohesion to the research pool and appreciate the breadth of domains that impact adherence to compression therapy, a scoping literature review was chosen. ${ }^{23}$ Due to the exploratory nature of the topic, this approach will allow for collation of information from multidisciplinary bodies of knowledge and allow mapping of key concepts and knowledge gaps.

\section{Protocol}

The PRISMA Extension for Scoping Reviews (PRISMAScR): Checklist and Explanation ${ }^{24}$ was used. A health librarian and second reviewer supported the process.

A priori protocol was developed and published on the Open Science Framework:

https://mfr.osf.io/render?url=https://osf.io/egn53/? direct $\% 26$ mode $=$ render $\% 26$ action $=$ download $\% 26$ mode $=$ render

\section{Design}

The design was composed of two phases. Firstly, the search strategy employed Arksey and O'Malley's methodological framework ${ }^{25}$ using an iterative approach allowing for a comprehensive review designed to identify all relevant literature regardless of study design. Following an analysis of the literature a conceptual framework was then developed, employing Jabareens' methodology ${ }^{26}$ linking multidisciplinary bodies of knowledge.

\section{Eligibility Criteria}

Using a PCC (population/ concept/ context) framework, ${ }^{27}$ the eligibility criteria were defined as: Population (included the target population of those with VLU or CVI), Concept (including any study that investigated modifiable variables relating to the use of compression stockings either as a direct outcome of a study, as an incidental finding or by comment by an expert, and Context (including any study that were of any study design and date of publication). Included were published articles and conference proceedings in the English language.

Exclusion criteria were studies that a) specifically focused on short-term/time-limited wearing of compression stockings, such as in pregnancy, for the treatment of deep vein thrombosis, "flight socks", TEDs (ThromboEmbolus Device), burns and post-vein surgical procedures, b) focused solely on the treatment of lymphoedema, c) looked exclusively at non-modifiable variables (such as climate, cognitive ability, access to stockings, religious or ethnic variables and others), d) were in languages other than English, e) were books, patents, or webpages, f) described compression delivered exclusively via other modalities eg bandaging, wrap systems or intermittent pneumatic pumps, and f) were not available in full text. Those papers that did not meet the criteria were removed. Subsequently, the full texts of the remaining studies were obtained and screened to determine eligibility. 


\section{Literature Search}

A search of the following electronic bibliographic databases was conducted: Medline, PubMed, CINAHL, Embase, Cochrane, Web of Science, Google Scholar and OT Seeker. The search strategy was peer-reviewed by an expert health librarian. The dates searched were from inception of the database till the final date of the search ( $25^{\text {th }}$ October 2019). References were downloaded from electronic search engines, inputted into an excel spreadsheet and then transferred to an electronic bibliographic system (ENDNOTE). Terms used in the search were as follows: compression/compression stocking/compression garment/compression sock/stockings/garments and adherence/compliance/concordance. While specifically interested in VLUs, we commenced our search looking at the broader scope of lower limb vascular conditions. The initial search using the MESH terms venous leg ulcers AND chronic venous insufficiency, excluded many relevant articles. When included as an "OR" MESH term, a nonsensical number of articles was identified hence the need to manually assess each article based on the parameters of this review. This enabled us to include papers that may have findings transferable to a broader population. This was then narrowed to include only those with CVI or VLU. Two phases of snowballing occurred to complement our search strategy.

\section{Data Analysis and Synthesis}

As the scope and nature of the available evidence was not known in advance, the development of categories and grouping for mapping purposes was developed iteratively as the data was extracted and tabulated. See Appendix 1 for data extraction template. Aligning with Jabareen's methodology, ${ }^{26}$ data was synthesized narratively by categories defined during the mapping process, to allow flexibility in development of themes to bring coherence to the data. A conceptual framework was logically constructed, around the theme of adherence. ${ }^{26,28}$ Using bibliographic analyses, papers were grouped by year of publication and further categorized using the Levels of Evidence Pyramid. ${ }^{29}$ As we were particularly interested to find out if any interventions have been able to influence adherence, RCTs and case reports/series were further analyzed to address the research questions. An analysis was conducted using frequencies supplemented by a narrative review. For consistency, data about adherence rates was converted from raw scores into a percentage to allow comparison across studies.

\section{Results}

Of 2613 articles originally identified through the application of search terms, 69 references were finally included for analysis. Figure 1 illustrates the PRISMA-ScR flow chart constructed. ${ }^{24}$ An overview of included studies is presented in Appendix 2. The initial search using the MESH terms venous leg ulcers AND chronic venous insufficiency, was too narrow and excluded many relevant articles. When included as an "OR" MESH term, a nonsensical number of articles was identified hence the need to manually assess each article based on the parameters of this review. Following an initial screening of title and abstract, the original number was reduced to 282 . Two separate phases of snowballing followed, manually screening reference lists from full-text articles, yielding a further 54 articles. Forty-eight duplicates were removed after the first phase of snowballing and a further 107 articles that did not meet inclusion criteria were removed after the second phase. Finally, 126 full text articles were printed and assessed for eligibility with a total of 57 excluded (reasons provided in Figure 1). This left 69 articles that fulfilled the eligibility criteria.

\section{Bibliographic Analysis Publications by Year}

There has been a steady increase in publications since 1991 (Figure 2). From 2011 to October 2019, 38 articles that met inclusion criteria have been published. No papers prior to 1991 were identified.

\section{Publications by Research Method}

The 69 included papers were grouped using the Levels of Evidence Pyramid ${ }^{29}$ (Figure 3). Four systematic reviews, three critically appraised topics, 14 randomized controlled trials, 17 prospective cohort designs, five retrospective cohort designs, nine case studies/reports, 13 background papers and four interview-based qualitative designs were identified.

\section{Developing a Conceptual Framework}

The themes emerging logically through scoping the multidisciplinary bodies of knowledge are visually represented in a conceptual framework (Figure 4). These themes are presented below, aligned to research questions 1-3. Research question 4 (knowledge gaps) is presented throughout. 


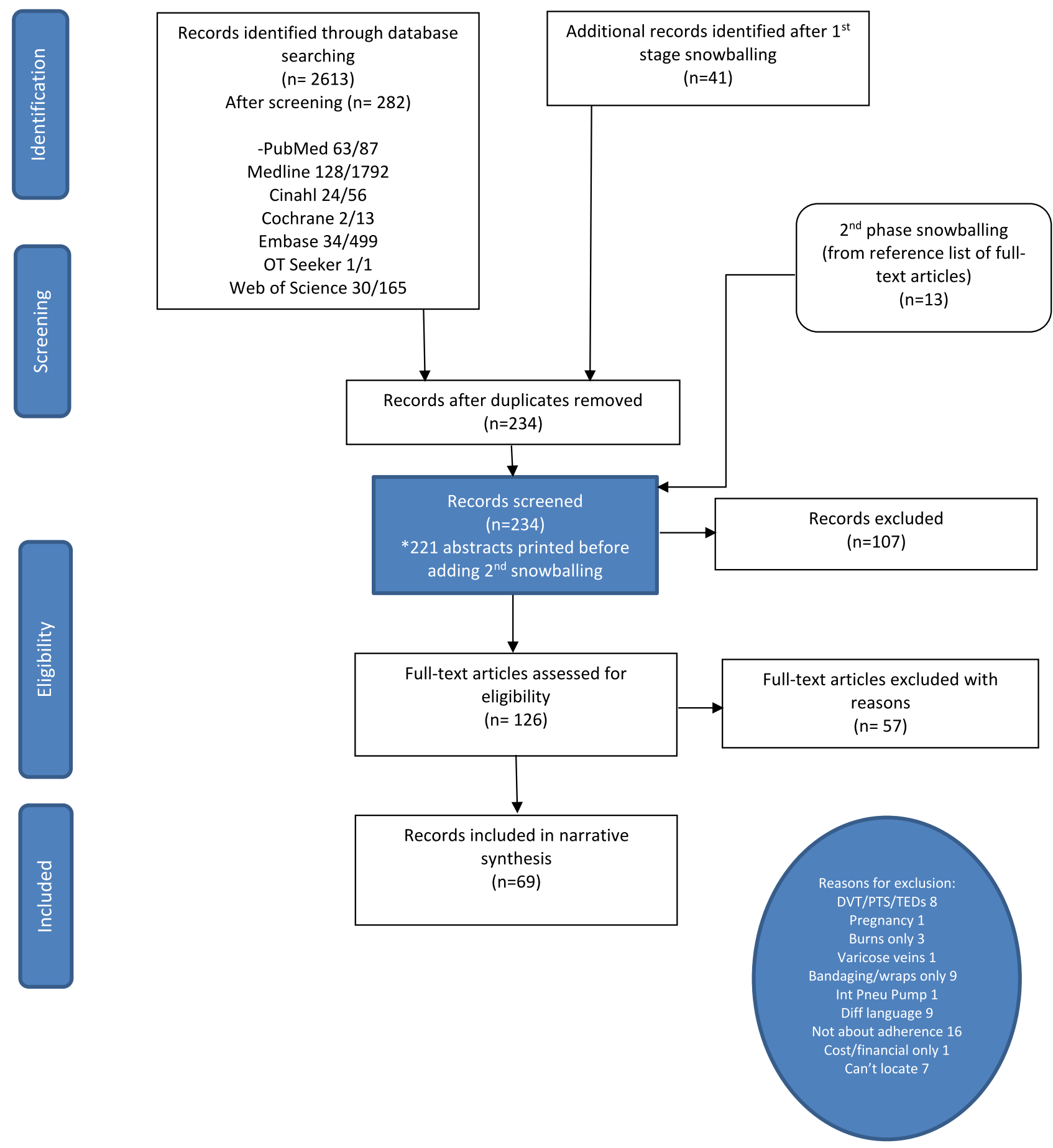

Figure I Study flow diagram (PRISMA-ScR flow chart ${ }^{24}$ ). Adapted from Tricco AC, Lillie E, Zarin W et al. PRISMA extension for scoping reviews (PRISMA-ScR): checklist and explanation. Ann Intern Med. 2018;169(7):467-473.

Modifiable Variables That Improve Adherence

Question one: What factors and interventions have been reported in the literature to attempt to improve compression stocking adherence?

A variety of interventions have been investigated but reported outcomes on adherence have not shown consistent or definitive preference for any intervention.
Consequently, the evidence does not currently support any intervention over others. Factors reported to improve patient adherence fell within three main themes: a) The way that health care professionals (HCPs) interact with patients, b) educational delivery designs, and c) variations in application and removal of stockings. Most studies with larger cohorts attempted to improve stocking adherence 
Number of publications per year

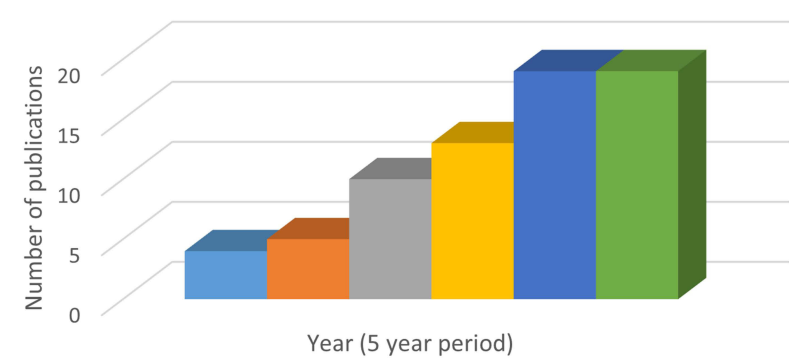

=1991-1995 $=1996-2000=2001-2005=2006-2010=2011-2015=2016-2019$ (Oct)

Figure 2 Number of publications by year from inception to conclusion of the search. through unidimensional approaches but reported limited impact. Conversely, some smaller studies $(\mathrm{N}=1-4)$ have generally reported positive impacts on adherence with personalized, multidimensional approaches. Table 1 summarizes the outcomes from interventions on adherence.

a) Fourteen articles ${ }^{6,21,30-41}$ discussed how HCPs can influence adherence. Predominantly discussion articles $(\mathrm{N}=12)$, only two (case studies) ${ }^{30,32}$ attempted to directly influence adherence. A review ${ }^{38}$ investigated stocking adherence after VLU healing, recommending that HCPs should ensure that their communication enhances the perceived value of compression stockings to improve

\section{Types of research methods}

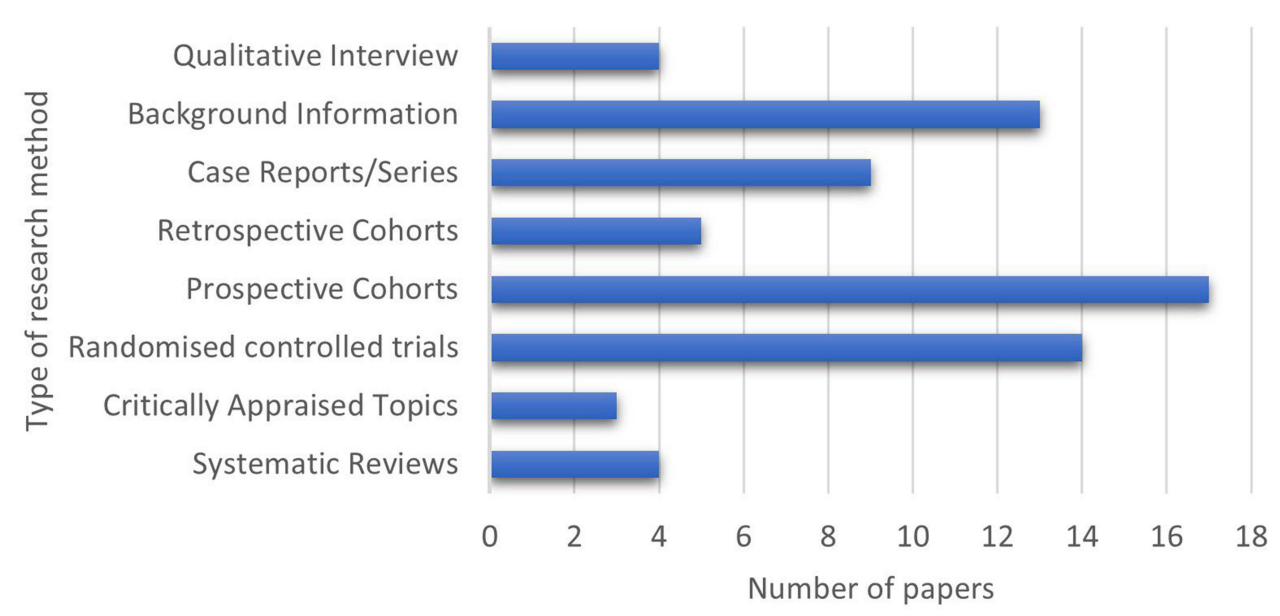

Figure 3 Publication count organized by level of evidence.

\section{Conceptual Framework: Adherence}

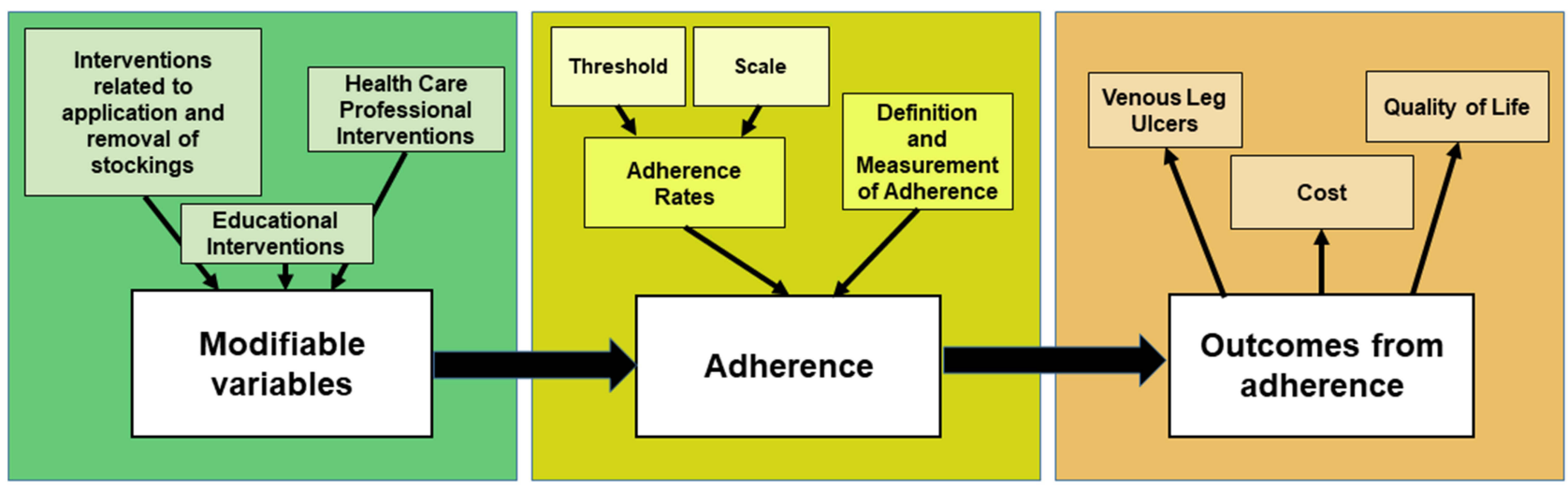

Figure 4 Conceptual Framework of Adherence. 
Table I Impact of Interventions on Adherence

\begin{tabular}{|c|c|c|c|c|}
\hline \multirow[t]{2}{*}{ Study } & \multirow[t]{2}{*}{ Type } & \multicolumn{2}{|c|}{ Variable(s) Modified } & \multirow[t]{2}{*}{ Adherence } \\
\hline & & Main & Second & \\
\hline Benigni, J.P., et $\mathrm{al}^{50}$ & RCT & $\begin{array}{l}\text { Stocking gradient (degressive versus } \\
\text { progressive) }\end{array}$ & Nil & $\begin{array}{l}\text { No measurable adherence outcome } \\
\text { provided }\end{array}$ \\
\hline Brooks, J., et al ${ }^{60}$ & RCT & Education program versus usual care & Nil & No significant difference between groups \\
\hline $\begin{array}{l}\text { Christensen, C.R. and } \\
\text { Yaeger, A.A. }{ }^{65}\end{array}$ & $\begin{array}{l}\text { Case } \\
\text { study }\end{array}$ & Patient contract (collaboration) & Bed alarm & Improved adherence for the case studied \\
\hline $\begin{array}{l}\text { Clarke-Moloney, M., } \\
\text { et al }\end{array}$ & RCT & Class I versus class 2 & Nil & Both groups improved equally \\
\hline Dickey, J.W.6 & $\begin{array}{l}\text { Case } \\
\text { series }\end{array}$ & $\begin{array}{l}\text { Unna's paste + elastic compression + } \\
\text { pump }\end{array}$ & Education & Improved adherence for the cases studied \\
\hline Franks, P.J., et $\mathrm{al}^{52}$ & RCT & Stocking brand I versus brand 2 & Nil & No significant difference between groups \\
\hline $\begin{array}{l}\text { Ham, S. and Padmore, } \\
\text { J. }^{46}\end{array}$ & $\begin{array}{l}\text { Case } \\
\text { series }\end{array}$ & Compression hosiery kits & Nurse training & Improved adherence for the cases studied \\
\hline Hampton, S. ${ }^{47}$ & $\begin{array}{l}\text { Case } \\
\text { study }\end{array}$ & Ready-wrap stockings & Carer training & Improved adherence for the case studied \\
\hline Heal, D. ${ }^{67}$ & $\begin{array}{l}\text { Case } \\
\text { series }\end{array}$ & Soft-fit addition & Nil & Improved adherence for the cases studied \\
\hline Heinen, M., et $\mathrm{al}^{61}$ & RCT & Education program versus usual care & Nil & No significant difference between groups \\
\hline Kapp, S., et al ${ }^{58}$ & RCT & Class 2 versus class 3 & Nil & Adherence higher in class 2 \\
\hline Krijnan, R.M.A., et al ${ }^{62}$ & RCT & Rubber mat versus stocking & Nil & No significant difference between groups \\
\hline $\begin{array}{l}\text { Lindsay, E and Hawkins, } \\
\text { J. }^{30}\end{array}$ & $\begin{array}{l}\text { Case } \\
\text { study }\end{array}$ & Collaboration with patient & $\begin{array}{l}\text { Various compression } \\
\text { styles }\end{array}$ & Improved adherence for the case studied \\
\hline $\begin{array}{l}\text { Lurie, F. and Schwatz, } \\
\text { M. }^{63}\end{array}$ & RCT & Pump versus stocking & Nil & No significant difference between groups \\
\hline Milic, D.J., et al ${ }^{45}$ & RCT & Class 2 versus class 3 & Nil & $\begin{array}{l}\text { Adherence higher in class } 2 \text { (not statistically } \\
\text { significant) }\end{array}$ \\
\hline Milic, D.J., et al ${ }^{64}$ & RCT & $\begin{array}{l}\text { Class } 3 \text { stocking versus bandaging } \\
\text { A versus bandaging } B\end{array}$ & Nil & $\begin{array}{l}\text { Adherence higher in class } 3 \text { (no significance } \\
\text { data provided) }\end{array}$ \\
\hline Mullins, M., et $\mathrm{al}^{48}$ & $\begin{array}{l}\text { Case } \\
\text { series }\end{array}$ & Extremit Ease (stocking with zipper) & Collaboration & Improved adherence for the cases studied \\
\hline Murdoch, $\mathrm{V}^{32}$ & $\begin{array}{l}\text { Case } \\
\text { study }\end{array}$ & Prescribing pyramid (collaboration) & $\begin{array}{l}\text { Various compression } \\
\text { styles }\end{array}$ & Improved adherence for the case studied \\
\hline Nelson, E.A., et al ${ }^{57}$ & RCT & Class 2 versus class 3 & Nil & Adherence higher in class 2 \\
\hline Protz, K., et al ${ }^{43}$ & RCT & Education program versus usual care & Nil & $\begin{array}{l}\text { Adherence higher in education group (no } \\
\text { significance data provided) }\end{array}$ \\
\hline Rees, R. $^{49}$ & $\begin{array}{l}\text { Case } \\
\text { study }\end{array}$ & High class to low class & Carer training & Improved adherence for the case studied \\
\hline Uhl, J., et $\mathrm{al}^{42}$ & RCT & Education program versus usual care & Nil & Adherence higher in the education group \\
\hline Zajkowski, P.J., et al ${ }^{53}$ & RCT & 4 stocking brands & Nil & No significant difference between groups \\
\hline
\end{tabular}


adherence. A case study ${ }^{30}$ described how one patient's healing rate improved when she was given more control over her own care, through a partnership formed with her nursing team. Another study ${ }^{32}$ highlighted the contribution of encouraging patient health ownership, which promoted autonomy, adherence and a better outcome. The development of a partnership between the HCP and the patient was specifically recommended in four articles. ${ }^{30,38,40,41}$ This is a situation where care plans are negotiated, and the HCP considers the patients' knowledge, experiences, beliefs, and practical needs. Emotive terms like empathy, ${ }^{33}$ honesty $^{34}$ and mutual respect ${ }^{32}$ are mentioned, with several papers ${ }^{21,34,36}$ advocating that patient-centered care is the gold standard to be achieved. The concept of developing a non-judgmental relationship, where no "blame" is placed on the patient, is also endorsed. ${ }^{6,18,31}$

b) In the theme of education, four studies ${ }^{41-43,60}$ used various modalities aiming to improve adherence. A quasi$\mathrm{RCT}^{43}$ showed benefit from using a brochure to improve patient knowledge, reporting that this led to higher adherence. A prospective cohort study ${ }^{60}$ reported that there was a different outcome depending on the source of the information provided. This study reported that adherence was greater amongst patients attended by vascular specialists (93\% adherence) as opposed to general practitioners (67\% adherence). An $\mathrm{RCT}^{42}$ concluded that repeated $\mathrm{HCP}$ recommendations followed by mobile phone text reminders increased adherence from $33 \%$ to $48 \%$ in the control group and to $71 \%$ in the intervention group. A nurse-led prospective cohort intervention ${ }^{41}$ used education as a primary tool to improve conservative management of VLUs, reporting that the education provided positively influenced participants' adherence to lifestyle advice generally but did not increase the amount of time that compression stockings were worn.

c) Fourteen articles ${ }^{45-58}$ reported on the participant's ability to manage the task of application or removal of stockings as an influential factor on adherence. Difficulty applying and removing compression stockings is a known barrier to adherence. ${ }^{54}$ Clinically it is acknowledged that some stockings are easier to apply than others (for example lighter compression). ${ }^{57,58}$ Also, certain physical attributes increase the ease of application, (for example lower body mass index). ${ }^{55}$ Twelve studies reported on interventions to attempt to improve adherence by varying specific properties of the stockings themselves. Three studies $^{49,51,56}$ compared light (class 1) to moderate (class 2) compression. The case study by Rees ${ }^{49}$ documented that the lighter compression improved adherence while the remaining two studies did not report statistically significant results. (Suehiro ${ }^{56}$ did not disclose results. Clarke-Moloney ${ }^{51}$ reported $\mathrm{P}=0.760$ ). Three further studies ${ }^{45,57,58}$ compared moderate (class 2) to high (class 3) compression and supported the widely held assumption that higher compression is less tolerated and more difficult to apply, though Milic's study ${ }^{45}$ did not report statistical significance $\mathrm{P}=0.188$. Nelson ${ }^{57}$ recommended that patients should wear the highest level of compression that is comfortable for them. Two studies $^{52,53}$ comparing brands of stockings demonstrated no difference in adherence rates and neither was easier to apply than the other. A $\mathrm{RCT}^{50}$ comparing a degressive (tighter at the calf and looser at the ankle) stocking to a progressive (standard graduation - tighter at the ankle and loser at the calf) found that the degressive stocking was easier to apply but did not significantly improve adherence. Other papers ${ }^{46-48}$ discussed alternative methods of applying compression stockings, for example an altered stocking design or adjustable compression wraps, with recommendations that these may assist to improve adherence in some patients who have difficulty with standard graduated compression stockings. The remaining papers included a qualitative analysis using structured interviews $^{55}$ and a literature review where the author ${ }^{54}$ recommended that all patients should be educated on the application of compression stockings and have application devices made available to them if needed.

Real-world studies such as case studies, may provide evidence on the effectiveness of an intervention in clinical practice, ${ }^{59}$ even though RCTs are considered gold standard for evaluating the efficacy of an intervention. Brought together, these different study types can add more depth to an understanding of an intervention. ${ }^{59}$ Further analysis of the 69 articles identified 23 studies attempting to directly influence adherence through modifying one or more variables, including $14 \mathrm{RCTs}^{42,43,45,50-53,57,58,60-64}$ and nine case studies (or case series)..$^{30,32,46-49,65-67}$ These were categorized by study design, and by the number and type of variables that were modified. The variables investigated are represented in Figure 5.

All RCTs modified a single variable within their study design, that is, they were unidimensional. Five of the 14 RCTs described an increase in adherence after the intervention. $\mathrm{One}^{42}$ was related to the variable of education, while three ${ }^{45,57,58}$ provided evidence that lowering compression strength may improve adherence but then increase risk of VLU recurrence. In a study ${ }^{64}$ comparing compression levels 


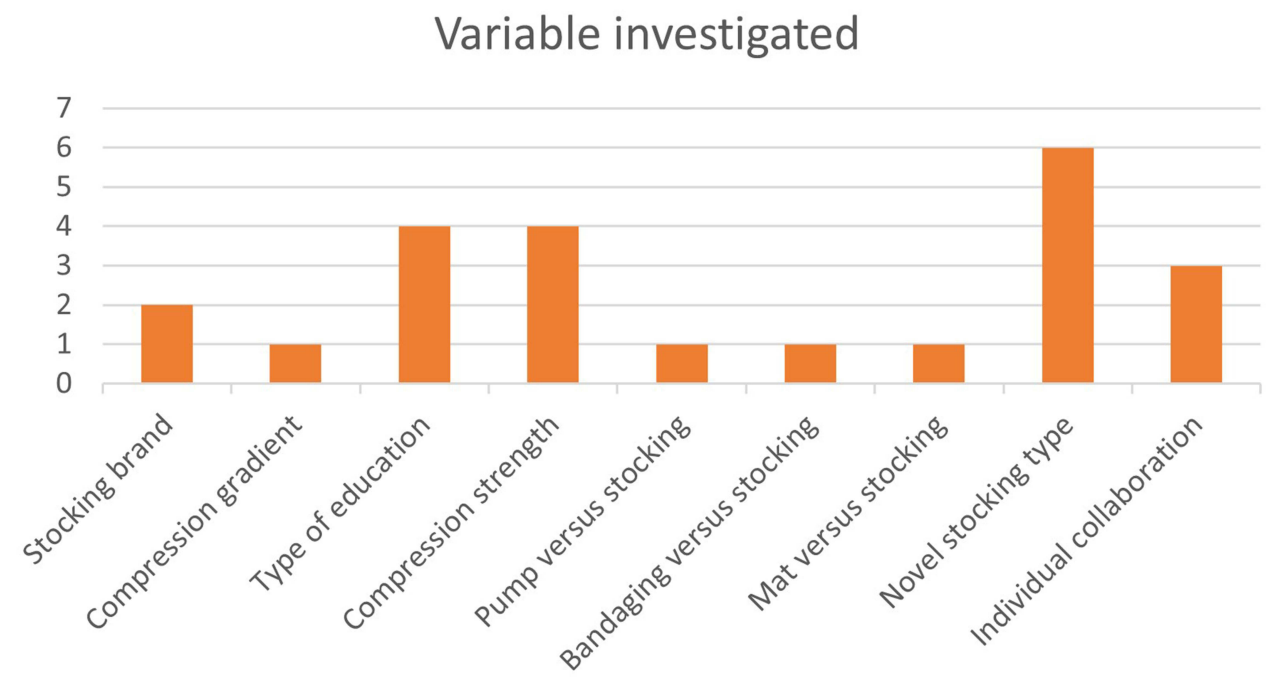

Figure $\mathbf{5}$ Variables investigated in the RCTs and case studies/series.

on adherence, the Class 3 group showed improved adherence compared to two types of bandaging, though no significance data was provided. Nine case studies/series described successful attempts to influence adherence. Six of these studies ${ }^{46-49,66,67}$ used personalized novel approaches to garment prescription (Velcro wraps, grip tops, zippers and compression kits) while three ${ }^{30,32,65}$ advocated for a personalized collaborative approach, involving health professionals and significant others in patient care. Eight of the nine case studies/series ${ }^{30,32,46-49,65,66}$ reported on a personalized multidimensional intervention, modifying at least two variables in the treatment plan.

\section{Adherence}

Question two: How has adherence been defined in the literature and how have adherence rates been reported and measured in the population of VLU and CVI?

Included studies present variable, and at times, conflicting descriptions of adherence, which are subject to interrelated concepts of the definition, measurement, and rate. Fourteen studies ${ }^{9,38,41,42,44,61,63,68-74}$ considered adherence a primary outcome measure where the remainder discussed adherence as a secondary outcome measure or as a point of discussion. Thirty studies reported a numerical adherence rate as an outcome of a study. Eight of the studies ${ }^{7,9,42,60,68,72,75,76}$ providing adherence rates did not give a clear definition of adherence. Studies defined adherence through various domains (adherence or a broader grouping with other factors) by measurement scale (dichotomous or interval) and/or with a stated threshold. Table 2 collates a meaningful sample of this information.

(a) Definitions of adherence: There is great variability in how adherence is defined. Only 28 of the 69 studies provided a description of their determination of adherence, and three of these $\mathrm{s}^{31,56,58} \mathrm{did}$ not describe how they measured it.

(b) Domains: Most studies reported exclusively on adherence in terms of compression wear alone, while some had a broader definition which included, for example, attendance at appointments, wound care, exercise, and leg elevation. ${ }^{41,60,61}$

(c) Scales: Of those who provided an adherence rate $(\mathrm{N}=30), \quad$ most $\quad(\mathrm{N}=18)^{12,16,44,45,56-}$ $58,60,62,63,68,73,74,77-81$ documented whether their participants were adherent or not adherent as a dichotomous score. That is, participants either followed the prescribed wearing protocol or not. Eleven studies described an interval scale $^{9,38,42,51,52,61,69,71,72,82,83}$ ranging from three to eight ranks, but only two ${ }^{38,51}$ of these explained which of their ranks were then classed as adherent or non-adherent. For example, Ayala ${ }^{69}$ utilized a 4-ranked interval scale to categorize stocking wear however did not describe which ranks was classed as adherent versus non-adherent.

(d) Thresholds: The variation in behavioral criteria for an adherent or non-adherent classification was considered. One hundred percent adherence was required in a study ${ }^{81}$ assessing adherence 
Table 2 Adherence: Measurement, Scale, Requirement for Achieving Adherence, and Rate

\begin{tabular}{|c|c|c|c|c|c|c|}
\hline \multirow[t]{3}{*}{ Process } & \multicolumn{6}{|c|}{ Measurement Scale } \\
\hline & \multicolumn{3}{|c|}{ Dichotomous } & \multicolumn{3}{|c|}{ Interval } \\
\hline & Study & $\begin{array}{l}\text { Requirement for Achieving } \\
\text { Adherence }\end{array}$ & Rate \% & Study & $\begin{array}{l}\text { Requirement for Achieving } \\
\text { Adherence }\end{array}$ & Rate \% \\
\hline \multirow[t]{5}{*}{$\begin{array}{l}\text { Self-reported } \\
\text { questionnaire }\end{array}$} & $\begin{array}{c}\text { Al } \\
\text { Shammeri } \\
\text { O, et } \mathrm{al}^{79}\end{array}$ & $\begin{array}{l}\text { Collected the CS from the store, } \\
\text { used it regularly and noticed an } \\
\text { effect (good, not comfortable, or } \\
\text { neutral) and would recommend it }\end{array}$ & 50 & \multirow[t]{5}{*}{$\begin{array}{l}\text { Clarke- } \\
\text { Moloney } \\
\text { M, et } \mathrm{al}^{51}\end{array}$} & \multirow{5}{*}{$\begin{array}{l}\text { All day every day - removing at night; } \\
\text { some part of each day; some days, } \\
\text { all day, and all night; or not at all^ } \\
\text { Dichotomy: All day every day - removing at } \\
\text { night versus the other alternatives }\end{array}$} & \multirow[t]{5}{*}{88.9} \\
\hline & $\begin{array}{l}\text { Cataldo J. } \\
\text { L, et al }\end{array}$ & Daily use exceeding 6 hours & 59.4 & & & \\
\hline & $\begin{array}{l}\text { Finlayson } \\
\mathrm{K} \text {, et } \mathrm{al}^{2}\end{array}$ & Daily use of CS & 47 & & & \\
\hline & $\begin{array}{l}\text { Shannon } \\
\text { M.M, } \\
\text { et } \mathrm{al}^{73}\end{array}$ & Wearing every day & 73 & & & \\
\hline & $\begin{array}{l}\text { Ziaja D, } \\
\text { et } \mathrm{al}^{74}\end{array}$ & $\begin{array}{l}\text { Wore stockings daily (not } \\
\text { occasionally) }\end{array}$ & 27,20 & & & \\
\hline $\begin{array}{l}\text { Self-reported } \\
\text { Journal }\end{array}$ & 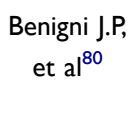 & $\begin{array}{l}\text { Worn for the minimum period (ie } 6 \\
\text { hours), equal or greater than } 80 \% \text { of } \\
\text { the time }\end{array}$ & 95 & & & \\
\hline \multirow[t]{5}{*}{$\begin{array}{l}\text { Self-report } \\
\text { Interview }\end{array}$} & \multirow[t]{5}{*}{$\begin{array}{l}\text { Krijnen R. } \\
\text { M.A, } \\
\text { et } \mathrm{al}^{62}\end{array}$} & \multirow[t]{5}{*}{ Wore CS almost every day at work } & \multirow[t]{5}{*}{66.6} & $\begin{array}{l}\text { Ayala A, } \\
\text { et al }\end{array}$ & $\begin{array}{l}\text { Not wearing at all/never, used } \\
\text { intermittently (up to } 50 \% \text { of the time), } \\
\text { most days ( } 50-100 \% \text { ) and, as } \\
\text { prescribed }{ }^{\wedge *}\end{array}$ & 31.8 \\
\hline & & & & $\begin{array}{l}\text { Franks P.J, } \\
\text { et } \mathrm{al}^{52}\end{array}$ & $\begin{array}{l}\text { All day every day; some of the day or } \\
\text { some days; some of the time }{ }^{\wedge *}\end{array}$ & $84+81$ \\
\hline & & & & $\begin{array}{l}\text { Heinen } \\
M \text {, et } \mathrm{al}^{61}\end{array}$ & $\begin{array}{l}\text { Always, all day; occasionally somewhat } \\
\text { shorter }<2 \text { hours }<1 \times \text { per week; } \\
\text { regularly somewhat shorter }<2 \text { hours } \\
\text { shorter }>1 \text { x per week; occasionally, } \\
\text { considerably shorter, }>2 \text { hours per } \\
\text { week; regularly, considerably shorter } \\
>2 \text { hours per week, }>\text { once per week; } \\
\text { occasionally not, for one day, less than } \\
\text { once per month; not, on a regular basis, } \\
\text { more than once per month; not, in the } \\
\text { last } 6 \text { months, more than one day at } \\
\text { a time }\end{array}$ & 45 \\
\hline & & & & $\begin{array}{l}\text { Heinen } \\
\text { M, et } \mathrm{al}^{70}\end{array}$ & $\begin{array}{c}8 \text { scales reduced to } 3 \text { : Fully; moderately } \\
\text { ( } 2 \text { hours less than all day); non- } \\
\text { adherent }^{\wedge *}\end{array}$ & 39 \\
\hline & & & & $\begin{array}{l}\text { Jull A. B, } \\
\text { et } \mathrm{al}^{38}\end{array}$ & $\begin{array}{l}\text { Wore stockings every day; most days; } \\
\text { occasionally; never^ } \\
\text { Dichotomy: Every day and most days } \\
\text { versus occasionally or never }\end{array}$ & 52 \\
\hline
\end{tabular}


Table 2 (Continued).

\begin{tabular}{|c|c|c|c|c|c|c|}
\hline \multirow[t]{3}{*}{ Process } & \multicolumn{6}{|c|}{ Measurement Scale } \\
\hline & \multicolumn{3}{|c|}{ Dichotomous } & \multicolumn{3}{|c|}{ Interval } \\
\hline & Study & $\begin{array}{l}\text { Requirement for Achieving } \\
\text { Adherence }\end{array}$ & Rate \% & Study & $\begin{array}{l}\text { Requirement for Achieving } \\
\text { Adherence }\end{array}$ & Rate \% \\
\hline \multirow[t]{5}{*}{$\begin{array}{l}\text { Professional } \\
\text { Recorded }\end{array}$} & $\begin{array}{l}\text { Brooks J, } \\
\text { et } \mathrm{al}^{60}\end{array}$ & Wore compression every day & $55-66$ & $\begin{array}{l}\text { Raju } S \text {, } \\
\text { et } \mathrm{al}^{72}\end{array}$ & $\begin{array}{l}\text { Daily wear (regular use); less consistent } \\
\text { (most days); infrequent use (sometimes } \\
\quad \text { or seasonally); not at all^*}\end{array}$ & 21 \\
\hline & $\begin{array}{l}\text { Erickson } \\
\text { C.A, } \\
\text { et } \mathrm{al}^{81}\end{array}$ & $\begin{array}{l}\text { Kept } 100 \% \text { of their appointments, } \\
\text { adhered completely with prescribed } \\
\mathrm{CS} \text {, and followed all instructions for } \\
\text { wound and extremity care }\end{array}$ & 32.3 & $\begin{array}{l}\text { Samson } \\
\text { R.H et al }\end{array}$ & $\begin{array}{l}\text { Good (well-fitting worn daily and new } \\
\text { CSs bought as necessary); poor (if } \\
\text { loose or worn-out CSs were used or } \\
\text { were worn irregularly); and none (CSs } \\
\quad \text { were not worn at all) } \\
\wedge\end{array}$ & 47 \\
\hline & $\begin{array}{l}\text { Mayberry } \\
\text { J.C, et al }\end{array}$ & $\begin{array}{c}\text { Wore stockings all day, removed at } \\
\text { night }\end{array}$ & 79 & & & \\
\hline & $\begin{array}{l}\text { Milic D. J, } \\
\text { et } \mathrm{al}^{45}\end{array}$ & $\begin{array}{l}\text { Wore CS } 80 \% \text { of the time during the } \\
\text { Ist and } 2 \text { nd years and }>50 \% \text { of the } \\
\text { time during } 3 \mathrm{rd}, 4 \text { th and } 5 \text { th years }\end{array}$ & $\begin{array}{l}89 \text { and } \\
93\end{array}$ & & & \\
\hline & $\begin{array}{l}\text { Stansal A, } \\
\text { et } \mathrm{al}^{44}\end{array}$ & $\begin{array}{l}\text { Wore CS to the appointment, } \\
\text { correctly applied, and effective }\end{array}$ & 89 & & & \\
\hline \multirow[t]{6}{*}{ Combination } & $\begin{array}{l}\text { Allaert F, } \\
\text { et } \mathrm{al}^{68}\end{array}$ & $\begin{array}{l}>3 \text { on Adhesig (Self-report via } \\
\text { questionnaire }+ \text { Thermosensors) }\end{array}$ & 74 & $\begin{array}{l}\text { Bogachev } \\
V \text {, et } \text { al }^{82}\end{array}$ & $\begin{array}{l}\text { As prescribed, most days, intermittently } \\
\text { or not at all^*}\end{array}$ & 29.1 \\
\hline & 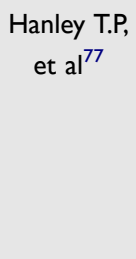 & $\begin{array}{c}\text { Wore CS on a regular basis (4-7 } \\
\text { days) each week (Observation and } \\
\text { self-report) }\end{array}$ & 37 & $\begin{array}{l}\text { Manduz S, } \\
\text { et } \mathrm{al}^{7 \mid}\end{array}$ & $\begin{array}{l}\text { CSs: suggested but did not buy; } \\
\text { recommended, bought but not used } \\
\text { enough; recommended, bought, and } \\
\text { used for a short time; recommended, } \\
\text { bought, and used irregularly; } \\
\text { recommended, bought, and still uses^*}\end{array}$ & Unclear \\
\hline & $\begin{array}{l}\text { Lurie } F \text {, } \\
\text { et al }{ }^{63}\end{array}$ & $\begin{array}{l}\text { Wore stockings during all wakeful } \\
\text { hours for } 30 \text { days. At least } 10 \text { hours } \\
\text { per day (Device meter and self- } \\
\text { report via diary) }\end{array}$ & 85 & & & \\
\hline & $\begin{array}{l}\text { Nelson } \mathrm{E} \text {. } \\
\mathrm{A} \text {, et } \mathrm{al}^{57}\end{array}$ & $\begin{array}{l}\text { Wore the allocated class of CS } \\
\text { throughout the study (Self-report } \\
\text { and observation) }\end{array}$ & $\begin{array}{l}58 \text { and } \\
72\end{array}$ & & & \\
\hline & $\begin{array}{l}\text { Uhl J, } \\
\text { et } \mathrm{al}^{42}\end{array}$ & $\begin{array}{l}\text { Average number of days worn (not } \\
\text { a definition per se }\end{array}$ & $\begin{array}{l}48 \text { and } \\
71\end{array}$ & & & \\
\hline & $\begin{array}{l}\text { Van Hecke } \\
\text { A, et } \text { al }^{41}\end{array}$ & $\begin{array}{c}\text { Wore every day except } 2-3 \text { days per } \\
\text { month, wore } 5-6 \text { days per week, }> \\
10 \text { hours per day (Self-report via } \\
\text { diary and interview) }\end{array}$ & $\begin{array}{c}\text { Not } \\
\text { provided }\end{array}$ & & & \\
\hline
\end{tabular}


Table 2 (Continued).

\begin{tabular}{|c|c|c|c|c|c|c|}
\hline \multirow[t]{3}{*}{ Process } & \multicolumn{6}{|c|}{ Measurement Scale } \\
\hline & \multicolumn{3}{|c|}{ Dichotomous } & \multicolumn{3}{|c|}{ Interval } \\
\hline & Study & $\begin{array}{l}\text { Requirement for Achieving } \\
\text { Adherence }\end{array}$ & Rate \% & Study & $\begin{array}{l}\text { Requirement for Achieving } \\
\text { Adherence }\end{array}$ & Rate \% \\
\hline \multirow[t]{4}{*}{$\begin{array}{l}\text { Not } \\
\text { described }\end{array}$} & 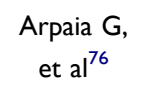 & Description not provided & 91.6 & & & \\
\hline & $\begin{array}{l}\text { Kapp S, } \\
\text { et } \mathrm{al}^{58}\end{array}$ & $\begin{array}{c}\text { Wore CS for }>50 \% \text { or nonadherent } \\
<50 \%\end{array}$ & 44.1 & & & \\
\hline & 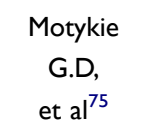 & Description not provided & 82 & & & \\
\hline & $\begin{array}{l}\text { Suehiro } K \text {, } \\
\text { et } \mathrm{al}^{56}\end{array}$ & CS worn $>5$ days per week & 80 & & & \\
\hline
\end{tabular}

Notes: ^Interval scale converted to dichotomized scale by study authors. *No explanation provided for conversion to dichotomous score. Abbreviation: CS, compression stockings.

related to physician instruction, while other studies $^{12,51}$ had broad categories with poorly defined threshold scores, for example a study that considered purchasing the stocking an assumption of adherence. ${ }^{71}$ It is assumed that the stricter the parameters to define adherence, the lower the reported adherence rate. For example, in Hanley's study, ${ }^{77}$ participants were classified as adherent if wearing their stockings 4-7 days per week. Similarly, Kapp's ${ }^{58}$ RCT classified adherence as wearing stockings more than $50 \%$ of study days. However, Franks ${ }^{52}$ study investigating VLU recurrence rates in patients wearing either of two different brands of stockings considered a participant adherent if they "wore their stockings all day every day", 52 demonstrating a much more arduous wearing regime required for their study participants to be classified as "adherent".

(e) Measurement: Eight studies $9,30,44,45,60,72,78,81$ relied purely on observation by a clinician (nurses or physi-

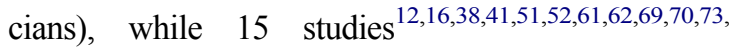
$74,79,80,82$ relied on patient self-report delivered either verbally or via questionnaire or journal. Three studies $^{57,71,77}$ used a combination of observation and self-report. A thermal-tracking device plus patient selfreport was used in three studies. ${ }^{42,63,68}$ Six studies did not disclose how their information was recorded or collected. ${ }^{7,56,58,64,75,76}$
Rates of adherence varied from 20.3 to $95 \%$. Due to the variability in definitions and measurement, reported adherence rates (reported in Table 2) have limited reliability.

\section{Outcomes from Adherence}

Question 3: What is the impact of adherence on patient outcomes?

Variable levels of adherence to medically prescribed compression stockings can influence a person's physical, social, and psychological situation in various ways. ${ }^{58}$ Outcome findings were separated into three key themes that appeared frequently in the literature, linking adherence to 1) VLU healing time/ recurrence 2) patient quality of life and 3) costs.

Studies that considered the link between adherence to stocking wear and VLU healing and recurrence were included and summarized in Table 3. Fifteen met these criteria, eight of which were RCTs, ${ }^{45,51,52,57,58,60,61,64}$ one was a systematic review, ${ }^{84}$ one $^{85}$ provided background information, another was a case series report ${ }^{66}$ and the remaining four were observational studies.9,77,78,81 All reported that low adherence with stocking wear is associated with delayed healing and increased recurrence of VLUs. Hanley ${ }^{77}$ reported that $25 \%$ of those who were adherent at 2 years of follow-up developed adverse sequential sequelae compared to $53 \%$ of those who were non-adherent. In Mayberry's study ${ }^{78}$ VLU healing occurred in $97 \%$ of those who were adherent versus $55 \%$ 
Table 3 Adherence and Reference to Healing Time and Recurrence

\begin{tabular}{|c|c|c|c|}
\hline Study & Variables Modified & Study Type & Outcome on VLU Healing/Recurrence \\
\hline $\begin{array}{l}\text { Brooks J, } \\
\text { et } \mathrm{al}^{60}\end{array}$ & $\begin{array}{l}\text { Usual care or education } \\
\text { program }\end{array}$ & $\begin{array}{l}\text { Quasi- } \\
\text { experimental } \\
\text { RCT }\end{array}$ & $\begin{array}{l}\text { There was } 4 \% \text { VLU recurrence in intervention group and } 36 \% \text { in control }(p=0.004) \text {. } \\
\text { Outcome not related to adherence but to ankle movement, mobility level and leg } \\
\text { elevation }\end{array}$ \\
\hline $\begin{array}{l}\text { Clarke- } \\
\text { Moloney M, } \\
\text { et } \mathrm{al}^{51}\end{array}$ & Class I or class 2 & Pilot RCT & $\begin{array}{l}\text { The lowest VLU recurrence rates were seen in patients who were adherent with } \\
\text { CSs regardless of the compression level. I2-month recurrence rate recorded } \\
\text { 16.3\%. All patients wearing class I stockings developed a new ulcer }{ }^{\#}\end{array}$ \\
\hline $\begin{array}{l}\text { Dahm K.T, } \\
\text { et } \mathrm{al}^{84}\end{array}$ & $\mathrm{~N} / \mathrm{a}$ & $\begin{array}{l}\text { Systematic } \\
\text { review }\end{array}$ & Class 2 seems to be more effective in prevention of ulcer recurrence than class $I^{\#}$ \\
\hline Dickey J.W66 & $\begin{array}{l}\text { Pre and post } \\
\text { intervention (CS and } \\
\text { education) }\end{array}$ & Case series & $\begin{array}{l}\text { An examination of the clinical course of each patient shows that the faster healing } \\
\qquad \text { was causally related to compliance }{ }^{\#}\end{array}$ \\
\hline 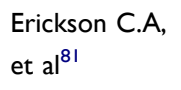 & $\begin{array}{l}\text { Pre and post Unna's boot } \\
+ \text { class } 3 \text { CS }\end{array}$ & $\begin{array}{l}\text { Retrospective } \\
\text { cohort }\end{array}$ & $\begin{array}{l}\text { Adherence reduced healing time and prolonged time to recurrence. At } 5 \text { months, } \\
\qquad \text { VLU healing was } 73 \% \text { if adherent, and } 59 \% \text { if non-adherent }{ }^{\#}\end{array}$ \\
\hline $\begin{array}{l}\text { Franks P.J, } \\
\text { et } \mathrm{al}^{52}\end{array}$ & Brand I or brand 2 & RCT & Recurrence rate was $26 \%$ after I year and $31 \%$ at 18 months for both brands $\#$ \\
\hline $\begin{array}{l}\text { Hanley T.P, } \\
\text { et } \mathrm{al}^{77}\end{array}$ & $\begin{array}{l}\text { Adherent or non- } \\
\text { adherent patient }\end{array}$ & $\begin{array}{l}\text { Prospective } \\
\text { cohort }\end{array}$ & $\begin{array}{l}\text { At } 2 \text { years the adherent group had no skin changes; } 28 \% \text { of non-adherent group had } \\
\text { skin changes including VLU in some. At } 60 \text { months none of the adherent group had } \\
\text { ulceration but } 8.6 \% \text { had stasis changes. Of non-adherent patients, } 63 \% \text { had chronic } \\
\text { skin changes }{ }^{\#}\end{array}$ \\
\hline $\begin{array}{l}\text { Heinen } M \text {, } \\
\text { et } \mathrm{al}^{61}\end{array}$ & $\begin{array}{l}\text { Usual care or lifestyle } \\
\text { counselling }\end{array}$ & RCT & $\begin{array}{l}\text { The intervention group had fewer wound days }(p<0.01) \text {, but time to recurrence did } \\
\text { not differ significantly }(p=0.07)^{<}\end{array}$ \\
\hline $\begin{array}{l}\text { Kapp S, } \\
\text { et al }\end{array}$ & Moderate CS or high CS & RCT & $\begin{array}{l}\text { Study wound recurrence was } \mid I .8 \% \text { within } 26 \text { weeks, and average time to } \\
\text { recurrence was } 77.9 \mid \text { days. Adherence to treatment significantly predicted study } \\
\text { wound recurrence }(p=0.005) \text {. Those who did not adhere to CS were } 9 \times \text { more likely } \\
\text { for the wound to recur. Recurrence risk was } 3 \times \text { greater for moderate compared to } \\
\text { high compression }\end{array}$ \\
\hline 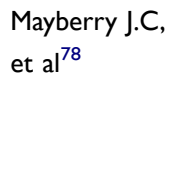 & Pre and post CS & $\begin{array}{l}\text { Prospective } \\
\text { cohort }\end{array}$ & $\begin{array}{c}\text { Of II } 3 \text { patients, } 102 \text { were compliant with CS: II were not. Only non-compliance } \\
\text { with CS }(\mathrm{p}<0.000 \mathrm{I}) \text { and a pre-treatment VLU duration of more than } 9 \text { months }(\mathrm{p}<- \\
0.02) \text { significantly decreased initial VLU healing. All noncompliant patients had } \\
\text { recurrent ulceration by } 36 \text { months } \#\end{array}$ \\
\hline $\begin{array}{l}\text { Milic D.J, } \\
\text { et } \mathrm{al}^{45}\end{array}$ & Class 2 or class 3 & RCT & $\begin{array}{l}\text { Class } 3 \text { had lower VLU recurrence rate compared to class } 2: 28.98 \% \text { versus } 60 \% \\
\qquad(\mathrm{P}<0.00 \mathrm{I})^{\#}\end{array}$ \\
\hline $\begin{array}{l}\text { Milic D.J, } \\
\text { et } \mathrm{al}^{64}\end{array}$ & $\begin{array}{c}\text { Class } 3 \text { CS or } 2 \text { types of } \\
\text { bandages }\end{array}$ & RCT & $\begin{array}{c}\text { The healing rate for VLU area of } 5-10 \mathrm{~cm}^{2} \text { in group } A \text { (Class } 3 \mathrm{CS} \text { ) was } 25 \%, 64 \% \text { in } \\
\text { group B (bandages) and } 75 \% \text { in group C (another type of bandages) }\end{array}$ \\
\hline $\begin{array}{l}\text { Moffat C, } \\
\text { et al }\end{array}$ & $\mathrm{N} / \mathrm{a}$ & $\begin{array}{l}\text { Critically } \\
\text { appraised }\end{array}$ & $\begin{array}{l}6 \text { studies indicate that the healing rate was half and the median time to complete } \\
\text { healing was twice as long when Pts were not concordant. Recurrence rates were 2- } \\
20 \text { times greater if not concordant post healing }\end{array}$ \\
\hline $\begin{array}{l}\text { Nelson E.A, } \\
\text { et al }\end{array}$ & Class 2 or class 3 & RCT & $\begin{array}{l}36 \% \text { had recurrent VLU by } 5 \text { years. } 39 \% \text { of these did not comply with their } \\
\text { randomized compression class in class } 3 \text {, and } 28 \% \text { in class } 2 \text {. No statistical difference } \\
\text { between classes on VLU recurrence, though fewer patients had ulcers in class } 3^{\#}\end{array}$ \\
\hline $\begin{array}{l}\text { Samson R.H } \\
\text { et al }\end{array}$ & Pre and post CS & $\begin{array}{l}\text { Prospective } \\
\text { cohort }\end{array}$ & $\begin{array}{c}\text { Of the } 25 \text { pts who were compliant only one developed a recurrence. Of the } 28 \text { who } \\
\text { were 'poor' or 'none', } 22 \text { developed at least one recurrence }\end{array}$ \\
\hline
\end{tabular}

Notes: ${ }^{<}$Adherence is the primary outcome measure. ${ }^{\#}$ VLU is the primary outcome measure.

Abbreviations: VLU, venous leg ulcer; CS, compression stockings. 
who were non-adherent, where all patients who were nonadherent had recurrent ulceration by 36 months. Moffat's 2009 review $^{85}$ identified that six of the ten studies included, reported that the medium time to complete healing was twice as long when patients were non-adherent. Furthermore, recurrence rates were 2-20 times greater if non-adherent post-healing. The evidence clearly suggests that adherence with compression therapy is vital in healing and prevention of VLUs and that the tighter the compression, the better. ${ }^{45,51,84}$

Seven papers ${ }^{6,41,42,55,63,75,80}$ discussed patient quality of life (QoL) as a clinical outcome measure of wearing compression stockings, however only three of these $\mathrm{e}^{42,63,75}$ used validated assessment tools, and the link between adherence and QoL was not well explored. A single paper reported that patients perceived compression to be "inconvenient and doubtful in improving quality of life". 55 However, this was an exception, as other included studies testified positively on QoL. Motykie ${ }^{75}$ reported that patients became less depressed about the appearance of their legs, began to sleep more routinely, and began to increase daily activity levels when they had commenced compression stocking wear. Using a thermal sensor to verify patient self-report, $\mathrm{Uhl}^{42}$ found that there is significant correlation between wearing time, and two parameters of a QoL questionnaire: psychic and social (both $\mathrm{P}<0.001$ ), however no correlation was found with physical or pain parameters. Only four of the included papers commented meaningfully on cost. ${ }^{7,9,16,32}$ Murdoch $^{32}$ reported that prevention of VLUs is generally more cost-effective than management of the resulting disorder.

\section{Discussion}

This is the first scoping review to report on the breadth of literature relating to adherence with compression stockings in the VLU and CVI population. Themes emerging from the literature and presented in a conceptual framework (Figure 4), revealed several key findings.

Firstly, with respect to variables that improved adherence, larger studies investigating unidimensional approaches reported little success. In contrast smaller, albeit less robust investigations of multidimensional approaches, hint at greater impact on improving adherence. As most patients with low adherence often have multiple barriers to wearing compression stockings, ${ }^{86}$ studies that modify only a single variable may not influence a proportion of study participants for whom that single variable is not relevant. It is also possible that multiple factors influence adherence and therefore interventions targeting a single variable may be destined to fail. This sentiment is echoed in recommendations for the management of other chronic diseases including diabetes mellitus ${ }^{87}$ and chronic kidney disease ${ }^{88}$ through acknowledgement of the complexities of individuals and their environments. The literature investigating unidimensional approaches lacks relevance for clinicians who gather information in multiple fields within their assessment. Van Hecke's 2009 literature review ${ }^{18}$ provided early support, recommending that future attempts to address the complex issue of low stocking adherence, should aim to consider comprehensive multidimensional packages, personalized to an individual's needs. Furthermore, neither unidimensional nor multidimensional studies that have attempted to improve adherence have been able to show a definitive preference for any intervention over others. Clinicians need greater evidence-based clarity regarding approaches to improve adherence with compression stockings and therefore further robust research into multidimensional patient centered approaches is needed.

Secondly, the lack of consistent definitions of adherence and measurement parameters underpins the wide range in reported adherence rates in the literature and simultaneously creates an impediment to clinical practice and research. For example, lower rates of adherence will be reported when stricter parameters must be complied with to meet the criteria for adherence and the converse relationship will also exist. Moffatt's ${ }^{85} 2009$ literature review reached a similar conclusion, attributing wide variability in reported adherence rates to contextual differences amongst trials. Dichotomous reporting of adherence may reduce the sensitivity of its measurement, yet the interval scales used to date, lack justification or explanation of their thresholds for defining adherence. Patient selfreport is the predominant method of measuring adherence, despite existing concerns around the validity of this method due to risk of memory bias and vulnerability to social desirability. ${ }^{89}$ A superior method of Thermotrackers does exist, but cannot be used in all climates, ${ }^{42,68}$ and their use could present an unacceptable cost to researchers. Van Hecke's 2009 literature review of studies reporting on reasons for low stocking adherence agreed with the findings from this review, where studies showed poor consistency in defining and operationalizing adherence. ${ }^{11}$ Lack of clarity and consistency in defining adherent behavior may undermine the reliability and validity of research findings. 
Finally, investigating the outcomes from adherence revealed that improved adherence correlates with improved health outcomes, which is consistent with prior authors. ${ }^{41,42}$ Despite the importance of cost, out of 69 included studies, only four in this review reported on this relationship. Some authors ${ }^{4,14}$ have reported a link between improving stocking adherence and reduced health costs but there remains a sparsity of health economic evidence regarding this link. Evidence suggests that there may be an improvement in quality of life for those who adhere with compression stockings because of a negative association between VLU and QoL, ${ }^{90}$ and because healing rates improve and recurrence decreases with better adherence, ${ }^{9,58,77}$ but studies in this review have included very limited information about this. Consequently, greater intelligence regarding the quality of life and economic impacts of improving adherence, are required from future research to better inform policy and funding in this area.

Several key gaps in the literature were identified. The lack of agreement in defining adherence with compression stockings, and the inconsistency in methods of measuring adherence is clearly evident from this review. The variations in behavioral criteria for an adherent or non-adherent determination between studies, restricts our confidence in making comparisons. The literature also reveals limited success in improving adherence to compression stocking wear in populations where each participant has unique and often multiple barriers to compression therapy. Personalized, multidimensional approaches to treatment have shown promise in small studies but have not been implemented in large populations. Health economic outcomes have not been adequately explored relating to different levels of adherence. Nor has the connection between quality of life and adherence been clarified.

\section{Directions for Future Research}

A consistent definition and scoring system for adherence would allow improved comparison between studies such as the standardized tools used to measure medication adherence. ${ }^{91}$ A more sensitive tool with an interval scale is needed. Personalized multidimensional approaches may be more likely to improve adherence. Future attempts to address this complex issue should aim to consider multidimensional packages, personalized to an individual's needs. Considerations include education, negotiation, and stocking selection tailored to patients' tolerance for compression and their ability to apply and remove stockings. Further, a high-quality trial to investigate the cost- effectiveness of such an intervention is recommended to improve our understanding of the financial implications and to consider any perceived patient and societal benefit.

\section{Strengths and Limitations of This Review}

A strength of this review is its breadth and overview of the topic, also the new synthesis of information to aid understanding of adherence with compression within this patient group.

This review also had some limitations. Firstly, some factors with potential to impact adherence were excluded on the basis that they are non-modifiable at the time of intervention, such as climate, cognitive ability, and religious beliefs. This was an intentional decision, to focus the review results and conclusions on modifiable factors more able to be targeted with subsequent clinical research. Finally, the search was limited to the English language as language translation was beyond the scope of this work. A further three studies ${ }^{92,93,94}$ that met inclusion criteria appear in Appendix 2 but are not cited in other tables or key themes within this review.

\section{Conclusion}

The often opaque and inconsistent way in which adherence with compression stockings has been measured and defined, currently limits meaningful comparison between studies, reducing the potential impact of clinical trials attempting to improving adherence. A variety of interventions have been investigated, but none have shown clear or consistent superiority over others. RCTs have generally investigated unidimensional interventions, which have been greatly unsuccessful in improving adherence. Multidimensional interventions have demonstrated more positive impacts on adherence but to date have only been investigated in smaller cohorts, case series or case studies. Improving adherence appears to improve health outcomes for patients with VLU/CVI but there is a lack of information directly linking improved adherence with cost outcomes. Consequently, the present evidence-base provides little support for clinicians seeking to improve patient adherence with compression. There is a need for highquality trials of multidimensional interventions targeting adherence with clear definitions and simultaneous cost evaluation.

\section{Abbreviations}

CEAP, system of classification of chronic venous disorders; CS, compression stocking; CVI, chronic venous 
insufficiency; HCP, health care professional; N, number; OTS, off the shelf; QoL, quality of life; RCT, randomized controlled trial; V, versus; VAS, visual analogue scale; VCSS, venous clinical severity score; VLU, venous leg ulcer.

\section{Acknowledgments}

Bronwyn Linthwaite. Head of Health Science and Medicine at Bond University Library for assistance with the literature search.

\section{Disclosure}

The authors report no conflicts of interest in this work.

\section{References}

1. Weller CD, Buchbinder R, Johnston RV. Interventions for helping people adhere to compression treatments for venous leg ulceration. Coch Database Syst Rev. 2016;3:CD008378.

2. Finlayson $\mathrm{K}, \mathrm{Wu} \mathrm{ML}$, Edwards HE. Identifying risk factors and protective factors for venous leg ulcer recurrence using a theoretical approach: a longitudinal study. Int J Nurs Stud. 2015;52 (6):1042-1051. doi:10.1016/j.jinurstu.2015.02.016

3. Stewart A, Edwards H, Finlayson K. Reflection on the cause and avoidance of recurrent venous leg ulcers: an interpretive descriptive approach. J Clin Nurs. 2018;27(5-6):931-939. doi:10.1111/ jocn.13994

4. Health Quality Ontario. Compression stockings for the prevention of venous leg ulcer recurrence: a health technology assessment. Ont Health Technol Assess Ser (Internet). 2019;19(2):1-86.

5. Todd M. Venous disease and chronic oedema: treatment and patient concordance. Br J Nurs. 2014;23(9):466, 468-470. doi:10.12968/ bjon.2014.23.9.466

6. Moffatt CJ. Factors that affect concordance with compression therapy. $J$ Wound Care. 2004;13(7):291-294. doi:10.12968/ jowc.2004.13.7.26641

7. Lindsay E. Compliance with science: benefits of developing community leg clubs. $B r \quad J$ Nurs. 2001;10(Suppl 22):66-68,70,72. doi:10.12968/bjon.2001.10.Sup5.12327

8. O'Meara S, Cullum N, Nelson EA, Dumville JC. Compression for venous leg ulcers. Coch Database Syst Rev. 2012;11:CD000265.

9. Samson RH, Showalter DP. Stockings and the prevention of recurrent venous ulcers. Dermatol Surg. 1996;22(4):373-376. doi:10.1111/ j.1524-4725.1996.tb00334.x

10. Brem H, Kirsner RS, Falanga V. Protocol for the successful treatment of venous ulcers. Am J Surg. 2004;188(Suppl 1A):1-8. doi:10.1016/ S0002-9610(03)00284-8

11. Van Hecke A, Grypdonck M, Defloor T. Interventions to enhance patient compliance with leg ulcer treatment: a review of the literature. J Clin Nurs. 2008;17(1):29-39.

12. Finlayson K, Edwards H, Courtney M. The impact of psychosocial factors on adherence to compression therapy to prevent recurrence of venous leg ulcers. J Clin Nurs. 2010;19(9-10):1289-1297. doi:10.1111/j.1365-2702.2009.03151.x

13. Graves N. Modelling the direct health costs of chronic wounds in Australia. Wound Prac and Res. 2014;22:20-33.

14. Australian Wound Management Association. KPMG. An economic evaluation of compression therapy for venous leg ulcers. Macquarie University Centre for the Health Economy; 2013. Available from: http://www.awma.com.au/publication:. Accessed October 1, 2019.
15. Cheng Q, Gibb M, Graves N, Finlayson K, Pacella RE. Costeffectiveness analysis of guideline-based optimal care for venous leg ulcers in Australia. BMC Health Serv Res. 2018;18(1):421. doi:10.1186/s12913-018-3234-3

16. Cataldo JL, de Godoy JM, de Barros N. The use of compression stockings for venous disorders in Brazil. Phlebology. 2012;27 (1):33-37. doi:10.1258/phleb.2011.010088

17. Kankam HKN, Lim CS, Fiorentino F, Davies AH, Gohel MS. A summation analysis of compliance and complications of compression hosiery for patients with chronic venous disease or post-thrombotic syndrome. Eur J Vasc Endovasc Surg. 2018;55 (3):406-416. doi:10.1016/j.ejvs.2017.11.025

18. Van Hecke A, Grypdonck M, Defloor T. A review of why patients with leg ulcers do not adhere to treatment. J Clin Nurs. 2009;18 (3):337-349. doi:10.1111/j.1365-2702.2008.02575.x

19. Haynes RB, Ackloo E, Sahota N, McDonald HP, Yao X. Interventions for enhancing medication adherence. Coch Database Syst Rev. 2008;1(2):CD000011.

20. Vitolins MZ, Rand CS, Rapp SR, Ribisl PM, Sevick MA. Measuring adherence to behavioral and medical interventions. Control Clin Trials. 2000;21(Suppl 5):188-194. doi:10.1016/S0197-2456(00)00077-5

21. Harker J. Influences on patient adherence with compression hosiery. J Wound Care. 2000;9(8):379-382. doi:10.12968/jowc.2000.9.8.26017

22. Tunis SR, Clarke M, Gorst SL, et al. Improving the relevance and consistency of outcomes in comparative effectiveness research. J Comp Eff Res. 2016;5(2):193-205. doi:10.2217/cer-2015-0007

23. Munn Z, Peters MDJ, Stern C, Tufanaru C, McArthur A, Aromataris E. Systematic review or scoping review? Guidance for authors when choosing between a systematic or scoping review approach. BMC Med Res Methodol. 2018;18(1):143. doi:10.1186/ s12874-018-0611-x

24. Tricco AC, Lillie E, Zarin W, et al. PRISMA extension for scoping reviews (PRISMA-ScR): checklist and explanation. Ann Intern Med. 2018;169(7):467-473. doi:10.7326/M18-0850

25. Arksey H, O’Malley L. Scoping studies: towards a methodological framework. Int J Soc Res Meth: Theory\& Prac. 2005;8(1):19-32. doi:10.1080/1364557032000119616

26. Jabareen Y. Building a conceptual framework: philosophy, definitions, and procedure. Int J Qual Meth. 2009;8:49-62. doi:10.1177/ 160940690900800406

27. Peters MDJ, Marnie C, Tricco AC, et al. Updated methodological guidance for the conduct of scoping reviews. JBI Evid Synth. 2020;18 (10):2119-2126. doi:10.11124/JBIES-20-00167

28. Bailey C, Madden A, Alfes K, et al. The meaning, antecedents and outcomes of employee engagement: a narrative synthesis. Int J Man Rev. 2017;19(1):31-53. doi:10.1111/ijmr.12077

29. Hoffman T, Bennett S, Del Mar C. Evidence-Based Practice Across the Health Professions. 2nd ed. Australia: McLinda McEvoy; 2013.

30. Lindsay E, Hawkins J. Care study: the Leg Club Model and the sharing of knowledge. $B r \quad J \quad$ Nurs. 2003;12(13):784-790. doi:10.12968/bjon.2003.12.13.11346

31. Bainbridge P. Why don't patients adhere to compression therapy? $\mathrm{Br}$ J Com Nurs. 2013;18(Sup12):35-40. doi:10.12968/bjcn.2013.18. Sup12.S35

32. Murdoch V. Patient concordance in the management of chronic oedema: role of the independent prescriber. $\mathrm{Br} J$ Comm Nurs. 2019;24(Suppl 4):6-10. doi:10.12968/bjen.2019.24.Sup4.S6

33. Anderson I. Optimising concordance with compression hosiery in the community setting. Br J Comm Nurs. 2015;20(2):67-68,70,72. doi:10.12968/bjen.2015.20.2.67

34. Brown A. Evaluating the reasons underlying treatment nonadherence in VLU patients: introducing the VeLUSET Part 1 of 2. $J$ Wound Care. 2014;23(1):37,40,42-34.

35. Brown A. Evaluating the reasons underlying treatment nonadherence in VLU patients: mishel's theory of uncertainty. Part 2 of 2. J Wound Care. 2014;23(2):73-77,80. doi:10.12968/jowc.2014.23.2.73 
36. Dissemond J, Assenheimer B, Bultemann A, et al. Compression therapy in patients with venous leg ulcers. J Germ Soc of Derm. 2016;14(11):1072-1087.

37. Jones J. Compression, ulcer recurrence and compliance. J Wound Care. 1998;7(Suppl 9):9-13. doi:10.12968/jowc.1998.7.Sup9.9

38. Jull AB, Mitchell N, Arroll J, et al. Factors influencing concordance with compression stockings after venous leg ulcer healing. $J$ Wound Care. 2004;13(3):90-92. doi:10.12968/jowc.2004.13.3.26590

39. Lay-Flurrie K. Use of compression hosiery in chronic oedema and lymphoedema. Bri J Nurs. 2011;20(7):418-422. doi:10.12968/ bjon.2011.20.7.418

40. Mudge E, Holloway S, Simmonds W, Price P. Living with venous leg ulceration: issues concerning adherence. $\mathrm{Br} J$ Nurs. 2006;15 (21):1166-1171. doi:10.12968/bjon.2006.15.21.22374

41. Van Hecke A, Grypdonck M, Beele H, Vanderwee K, Defloor T. Adherence to leg ulcer lifestyle advice: qualitative and quantitative outcomes associated with a nurse-led intervention. J Clin Nurs. 2011;20(3-4):429-443. doi:10.1111/j.1365-2702.2010.03546.x

42. Uhl J-F, Benigni J-P, Chahim M, Frederic D. Prospective randomized controlled study of patient compliance in using a compression stocking: importance of recommendations of the practitioner as a factor for better compliance. Phlebology. 2018;33(1):36-43. doi:10.1177/ 0268355516682886

43. Protz K, Dissemond J, Seifert M, et al. Education in people with venous leg ulcers based on a brochure about compression therapy: a quasi-randomised controlled trial. Int Wound J. 2019;2:1-11.

44. Stansal A, Lazareth I, Michon Pasturel U, et al. Compression therapy in 100 consecutive patients with venous leg ulcers. J Mal Vasc. 2013;38(4):252-258. doi:10.1016/j.jmv.2013.05.006

45. Milic DJ, Zivic SS, Bogdanovic DC, Golubovic MD, Lazarevic MV, Lazarevic KK. A randomized trial of class 2 and class 3 elastic compression in the prevention of recurrence of venous ulceration. $J$ Vasc Surg Venous Lymphat Disord. 2018;6(6):717-723. doi:10.1016/j.jvsv.2018.06.009

46. Ham S, Padmore J. Two-layer compression hosiery for patients with venous leg ulceration. Nurs Stand. 2006;20(45). doi:10.7748/ ns.20.45.68.s58

47. Hampton S. The difficulty and the solution of compression therapy in a healed venous leg ulcer. Br J Comm Nurs. 2016;21(Suppl 9):34-38. doi:10.12968/bjen.2016.21.Sup9.S34

48. Mullins M, Bock K, Bhatia A. Extremit-Ease compression garment: a review and cases. Bri J Comm Nurs. 2017;22:41-47. doi:10.12968/ bjen.2017.22.Sup12.S41

49. Rees T. Use of compression therapy in venous leg ulceration. Nurs Stand. 2002;17(6):51-56. doi:10.7748/ns.17.6.51.s53

50. Benigni JP, Branchoux S, Bacle I, Taieb C. Difficulty associated with donning medical compression stockings: results from a survey comparing two different compression stockings. Womens Health. 2013;9 (3):291-300.

51. Clarke-Moloney M, Keane N, O’Connor V, et al. Randomised controlled trial comparing European standard class 1 to class 2 compression stockings for ulcer recurrence and patient compliance. Int Wound J. 2014;11(4):404-408. doi:10.1111/j.1742-481X.2012.01108.x

52. Franks PJ, Oldroyd MI, Dickson D, Sharp EJ, Moffatt CJ. Risk factors for leg ulcer recurrence: a randomized trial of two types of compression stocking. Age Ageing. 1995;24(6):490-494. doi:10.1093/ageing/24.6.490

53. Zajkowski PJ, Proctor MC, Wakefield TW, Bloom J, Blessing B, Greenfield LJ. Compression stockings and venous function. Arch Surg. 2002;137(9):1064-1068. doi:10.1001/archsurg.137.9.1064

54. Balcombe L, Miller C, McGuiness W. Approaches to the application and removal of compression therapy: a literature review. $\mathrm{Br} J \mathrm{Comm}$ Nurs. 2017;22(Suppl 10):6-14. doi:10.12968/bjen.2017.22.Sup10.S6

55. Baranski K, Chudek J. Factors affecting patients' self-management in chronic venous disorders: a single-center study. Patient Pref and Adher. 2016;10:1623-1629. doi:10.2147/PPA.S110773
56. Suehiro K, Morikage N, Yamashita O, et al. Adherence to and efficacy of different compression methods for treating chronic venous insufficiency in the elderly. Phlebology. 2016;31(10):723-728. doi:10.1177/0268355515608992

57. Nelson EA, Harper DR, Prescott RJ, Gibson B, Brown D, Ruckley CV. Prevention of recurrence of venous ulceration: randomized controlled trial of class 2 and class 3 elastic compression. J Vasc Surg. 2006;44(4):803-808. doi:10.1016/j.jvs.2006.05.051

58. Kapp S, Miller C, Donohue L. The clinical effectiveness of two compression stocking treatments on venous leg ulcer recurrence: a randomized controlled trial. Int J Low Extr Wound. 2013;12 (3):189-198. doi:10.1177/1534734613502034

59. Tashkin DP, Amin AN, Kerwin EM. Comparing randomized controlled trials and real-world studies in chronic obstructive pulmonary disease pharmacotherapy. Int $J$ Chron Obstruct Pulmon Dis. 2020;15:1225-1243. doi:10.2147/COPD.S244942

60. Brooks J, Ersser SJ, Lloyd A, Ryan TJ. Nurse-led education sets out to improve patient concordance and prevent recurrence of leg ulcers. $J$ Wound Care. 2004;13(3):111-116. doi:10.12968/jowc.20 04.13.3.26585

61. Heinen M, Borm G, van der Vleuten C, Evers A, Oostendorp R, van Achterberg T. The Lively Legs self-management programme increased physical activity and reduced wound days in leg ulcer patients: results from a randomized controlled trial. Int J Nurs Stud. 2012;49(2):151-161. doi:10.1016/j.ijnurstu.2011.09.005

62. Krijnen R. Compression stockings and rubber floor mats: do they benefit workers with chronic venous insufficiency and a standing profession? J Occ Environ Med. 1997;39(9):889-894. doi:10.1097/ 00043764-199709000-00013

63. Lurie F, Schwartz M. Patient-centered outcomes of a dual action pneumatic compression device in comparison to compression stockings for patients with chronic venous disease. J Vasc Surg Venous and Lymph Dis. 2017;5(5):699-706.

64. Milic DJ, Zivic SS, Bogdanovic DC, et al. The influence of different sub-bandage pressure values on venous leg ulcers healing when treated with compression therapy. J Vasc Surg. 2010;51(3):655-661. doi:10.1016/j.jvs.2009.10.042

65. Christensen CR, Yeager AA. Case study: a unique approach to compliance in a patient with venous ulcers. J Vasc Nurs. 2001;19 (2):52-54. doi:10.1067/mvn.2001.115783

66. Dickey JW. Stasis ulcers: the role of compliance in healing. South Med J. 1991;84(5):557-561.

67. Heal D. Improving patient concordance in lymphoedema management with SoftFit technology. Br J Comm Nurs. 2017;22(Suppl 5):22-S27. doi:10.12968/bjen.2017.22.Sup5.S22

68. Allaert F-A, Rastel D, Graissaguel A, Sion D, Hamel-Desnos C. Design and evaluation of the psychometric properties of a self-questionnaire on patient adherence to wearing elastic compression stockings. Phlebology. 2019;34(1):25-31. doi:10.1177/ 0268355518762824

69. Ayala A, Guerra JD, Ulloa JH, Kabnick L. Compliance with compression therapy in primary chronic venous disease: results from a tropical country. Phlebology. 2019;34(4):272-277. doi:10.1177/ 0268355518798153

70. Heinen MM, van der Vleuten C, de Rooij MJ, Uden CJ, Evers AW, van Achterberg T. Physical activity and adherence to compression therapy in patients with venous leg ulcers. Arch Dermatol. 2007;143 (10):1283-1288. doi:10.1001/archderm.143.10.1283

71. Manduz S, Ada F, Ada Y. The level of awareness and the attitude of patients recommended for use of compression stockings in Turkish society, and investigation of the factors affecting their use. Patient Pref and Adher. 2018;12:399-407. doi:10.2147/PPA. S157344

72. Raju S, Hollis K, Neglen P. Use of compression stockings in chronic venous disease: patient compliance and efficacy. Ann Vasc Surg. 2007;21(6):790-795. doi:10.1016/j.avsg.2007.07.014 
73. Shannon MM, Hawk J, Navaroli L, Serena T. Factors affecting patient adherence to recommended measures for prevention of recurrent venous ulcers. J Wound Ostomy Cont Nurs. 2013;40(3):268-274. doi:10.1097/WON.0b013e318285081a

74. Ziaja D, Kocelak P, Chudek J, Ziaja K. Compliance with compression stockings in patients with chronic venous disorders. Phlebology. 2011;26(8):353-360. doi:10.1258/phleb.2010.010086

75. Motykie GD, Caprini JA, Arcelus JI, Reyna JJ, Overom E, Mokhtee D. Evaluation of therapeutic compression stockings in the treatment of chronic venous insufficiency. Derm Surg. 1999;25 (2):116-120. doi:10.1046/j.1524-4725.1999.08095.x

76. Arpaia G, Milani M, Addeo R, et al. Clinical validation of a specially sized class II compression knee-sock for the prevention of recurrent ulcers in patients with chronic venous stasis (CEAP 5). Int Angiol. 2008;27(6):507-511.

77. Hanley T. Long-term prevention of sequelae of chronic venous disease with graduated-compression stockings. J Wound Care. 1997;4:451-455.

78. Mayberry JC. Fifteen-year results of ambulatory compression therapy for chronic venous ulcers. Surg. 1991;109:575-581.

79. Al Shammeri O, AlHamdan N, Al-Hothaly B, Midhet F, Hussain M, Al-Mohaimeed A. Chronic venous insufficiency: prevalence and effect of compression stockings. Int J Sci. 2014;8(3):231-236.

80. Benigni JP, Sadoun S, Allaert FA, Vin F. Efficacy of class 1 elastic compression stockings in the early stages of chronic venous disease: a comparative study. Int Ang. 2003;22(4):383-392.

81. Erickson CA, Lanza DJ, Karp DL, et al. Healing of venous ulcers in an ambulatory care program: the roles of chronic venous insufficiency and patient compliance. J Vasc Surg. 1995;22(5):629-636. doi:10.1016/S0741-5214(95)70051-X

82. Bogachev V, Arribas JMJ, Baila S, et al. Management and evaluation of treatment adherence and effectiveness in chronic venous disorders: results of the international study VEIN Act Program. Drugs and Therapy Perspec. 2019;35(8):396-404. doi:10.1007/s40267-019-00637-5

83. Heinen MM, Bartholomew LK, Wensing M, Pvd K, Achterberg T. Supporting adherence and healthy lifestyles in leg ulcer patients: systematic development of the Lively Legs program for dermatology outpatient clinics. Pat Educ and Couns. 2006;61(2):279-291. doi:10.1016/j.pec.2005.04.007

84. Dahm KT, Myrhaug HT, Stromme H, Fure B, Brurberg KG. Effects of preventive use of compression stockings for elderly with chronic venous insufficiency and swollen legs: a systematic review and meta-analysis. BMC Geriatr. 2019;19(1):76. doi:10.1186/s12877019-1087-1
85. Moffatt C, Kommala D, Dourdin N, Choe Y. Venous leg ulcers: patient concordance with compression therapy and its impact on healing and prevention of recurrence. Int Wound J. 2009;6 (5):386-393. doi:10.1111/j.1742-481X.2009.00634.x

86. Chitambira F. Patient perspectives: explaining low rates of compliance to compression therapy. Wound Prac and Res. 2019;27 (4):168-174.

87. Kim H, Son H. Fatigue-related factors for community-dwelling older adults with diabetes: a theory-guided multi-dimensional approach using the dynamic biopsychosocial model. Int J Environ Res Public Health. 2019;16(22):4502. doi:10.3390/ijerph16224502

88. Pagels AA, Hylander B, Alvarsson M. A multi-dimensional support programme for patients with diabetic kidney disease. J Ren Care. 2015;41(3):187-194. doi:10.1111/jorc.12114

89. Stirratt MJ, Dunbar-Jacob J, Crane HM, et al. Self-report measures of medication adherence behavior: recommendations on optimal use. Transl Behav Med. 2015;5(4):470-482. doi:10.1007/s13142-0150315-2

90. Clarke-Moloney M, O’Brien JF, Grace PA, Burke PE. Health-related quality of life during four-layer compression bandaging for venous ulcer disease: a randomised controlled trial. Ir J Med Sci. 2005;174 (2):21-25. doi:10.1007/BF03169124

91. Tan X, Patel I, Chang J. Review of the four item Morisky medication adherence scale (MMAS-4) and eight item Morisky medication adherence scale (MMAS-8). Innov in Pharm. 2014;5(3):1-8. doi:10.24926/iip.v5i3.347

92. Jindal R, Uhl J-F, Benigni JP. Sizing of medical below-knee compression stockings in an Indian population: a major risk factor for non-compliance. Phlebology. 2020;35:110-124. doi:10.1177/ 0268355519854611

93. Kolluri R. Compression therapy for treatment of venous disease and limb swelling. Curr Treat Options in Cardiovasc Med. 2011;13 (2):169-178. doi:10.1007/s11936-011-0114-0

94. Uhl J, Benigni J, Chahim M, Cornu-Thenard A. Use of compression stockings in chronic venous disease: validation of a new device to assess patient compliance. J Vasc Surg Venous Lymph Dis. 2015;3 (1):131.
Patient Preference and Adherence

\section{Publish your work in this journal}

Patient Preference and Adherence is an international, peer-reviewed, open access journal that focusing on the growing importance of patient preference and adherence throughout the therapeutic continuum. Patient satisfaction, acceptability, quality of life, compliance, persistence and their role in developing new therapeutic modalities and compounds to optimize clinical outcomes for existing disease states are major areas of interest for the journal. This journal has been accepted for indexing on PubMed Central. The manuscrip management system is completely online and includes a very quick and fair peer-review system, which is all easy to use. Visit http:// www.dovepress.com/testimonials.php to read real quotes from published authors. 